\title{
Application of Electron Beam Irradiation Technique for Shelf-Life Extension of Animal Food Products
}

\author{
Zehra Nur Ozer ${ }^{*}$ \\ 1 Afyon Kocatepe University, Science and Literature Faculty, Physics Department, 03200, Afyonkarahisar, Turkey
}

\begin{abstract}
For food processing gamma rays, electron beam and X-rays are used for disinfection of microorganisms and for extension of the shelf-life of the food. Electron beam irradiation process and its facilities are discussed widely for animal food products, nowadays. Although there are many advantages of this technique, high doses may be needed to achieve desired purposes. The irradiation conditions such as irradiation energy, dose and speed, penetration depth, processing speed should be optimized for such an irradiation apparatus design. The type and the size of the food; if it is fresh, frozen or in packets; transition process to atmospheric medium and irradiation parameters are the issues that need to be adjusted carefully according to aims. In this work, design parameters of an electron beam irradiation system are described and simulation of a low energy electron curtain accelerator is introduced. This study was carried out as the first step with the construction idea of a system that is planned to be made most appropriately in the current laboratory conditions. Also is to demonstrate the operability of such a system at low energies for sterilization on the surface of the target material.
\end{abstract}

Key words: Electron beam, electron accelerator, electron beam irradiation of food, food irradiation, animal products.

Elektron Demeti ile Işınlama Tekniğinin Hayvansal Ürünlerin Raf Ömrünün Uzatılmasında Kullanımı

ÖZ

Gıda 1şınlama sürecinde mikroorganizmaların dezenfeksiyonu ve gıdanın raf ömrünün uzatılması için gama 1şınları, elektron ışını ve X 1şınları kullanılır. Günümüzde, hayvansal gıda ürünleri için elektron demeti ile 1şınlama işlemi ve tesisleri yaygın olarak tartışılmaktadır. Bu tekniğin birçok avantajı olmasına rağmen, hedefe ulaşmak için yüksek dozlara ihtiyaç duyulabilmektedir. Işınlama enerjisi, dozu ve hızı, penetrasyon derinliği, işlem hızı gibi 1şınlama koşulları, bu tip bir ışınlama sistemi tasarımı için optimize edilmelidir. Gıdaların taze, dondurulmuş veya paketler halinde olması, tipi ve büyüklüğü, atmosfer ortamına geçiş süreci ve ışınlama parametreleri hedefe göre dikkatlice ayarlanması gereken parametrelerdir. Bu çalışmada, elektron demeti ile ışınlama sisteminin tasarım parametreleri açılanmış ve düşük enerjili bir elektron hızlandırıcısının simülasyonu tanıtılmışır. Bu çalışma, mevcut laboratuvar koşullarında yapılması planlanan bir sistemin tasarımı fikrinin ilk adımı olarak gerçekleştirilmiştir. Ayrıca böyle bir sistemin hedef malzemenin yüzeyi üzerine uygulanması ile sterilizasyon gibi uygulamalar için düşük enerjilerde çalışabileceği gösterilmiştir.

Anahtar Kelimeler: Elektron demeti, elektron hızlandırıcısı, gıdaların elektron demeti ile 1şınlaması, gıda 1şınlaması, hayvansal ürün.

To cite this article: Ozer Z.N. Application of Electron Beam Irradiation Technique for Shelf-Life Extension of Animal Food Products. Kocatepe Vet J. (2020) 13(4)413-419

Submission: 14.04.2020 Accepted: 23.11.2020

Published Online: 25.11.2020

ORCID ID; ZNÖ: 0000-0002-5887-4486

*Corresponding author e-mail: zehraerengil@aku.edu.tr 


\section{INTRODUCTION}

Food irradiation is one of the foreseen methods that can control the growth of microorganisms, parasites, insects and some losses that may occur during slaughtering, processing and transporting. By food irradiation, prevention of foodborne illness, and food hygiene security are aimed. Irradiation applications are also used to extend the shelf life of food products. Irradiation has about 100 years of history and is specified for safe food processes (Molins et al. 2001, Farkas and Farkas2011). It is confirmed by organizations of the World Health Organization (WHO), the Food and Agriculture Organization (FAO), and the International Atomic Energy Agency (IAEA) as being effective in achieving the aforementioned purpose and a safe, nutritional suitable method since 1980 s.

Irradiation does not cause radioactivity in foods, actually it is an energy input on them. The amount of this energy is irradiation absorption defined as dose in the unit of gray (Gy), (Ferreira et al. 2017). The superiority of the strong ability of irradiation to penetrate in materials breaks both structural, metabolic functions and lead to fragmentation of DNA. Hence, results as the eventual death of microbial cells. Intensive and much-localized energy, namely uniform energy is imparted to the material and in this way; a sufficient level of sterilization impact can be obtained with a little increase in the whole temperature of that material. Herewith, the irradiation process is very convenient for fresh fruits and vegetables, meat, and other animal products, and frozen foods.

Irradiation process helps to reduce the microorganism activities, to prevent parasite contamination sources and prevent diseases, to remove pests and sterile products, to eliminate some of the chemicals used for foods, and also to reduce fungicide residue problem with food (Lagunas-Solar 1995, Olson 1998, Korel and Orman 2005, Goresline2018). The US Department of Agriculture's (USDA's) Food Safety and Inspection Service announced a voluntarily recall of approximately $46000 \mathrm{lbs}$ of ground beef for possible Escherichia coli O157:H7 contamination. The detection of such pathogenic bacteria in ground beef caused a reduction in beef consumption and huge economic losses.

In some studies, it has been seen that irradiation significantly reduces foodborne pathogen concentrations (Kwon et al. 2008, Arthur 2005). In recent years, irradiation has been approved for the processing of chilled or frozen uncooked meat and meat by-products (U.S. Department of Agriculture, Food Safety and Inspection Service. 1999). To process these products, high penetration, and high energy radiation might be needed to provide the entire meat product and both exposed surface and internal regions are irradiated. The increasing number of foodborne bacteria as Escherichia coli O157:H7, Pseudomonas spp., Listeria monocytogenes, Staphylococcus aureus, and Bacillus cereus (Taha 1999, Woodburn and Raob 1997, Park et al. 2010) particularly Salmonella has increased interest in food irradiation as an effective technique for the disposal (Min et al. 2005). For eliminating pathogens in heat-sensitive products like eggs, the irradiation process can be more attractive (Radomyski et al. 1994, Arvanitoyannis 2010). However, the effects of irradiation on the physicochemical and functional properties of shell eggs and liquid egg yolk and white are still argumentative.

Gamma, X-rays, and accelerated electron beams are used mostly in the industry for various applications as well as food irradiation (Ozer 2017). Gamma rays from Co-60 or Cs-137 (below $5 \mathrm{MeV}$ energy level) are commonly used since they have high penetrating power, low dose rate, and foods can be irradiated with their thick coverage packages. On the other hand, electron beams are generated (below $10 \mathrm{MeV}$ energy level) with low penetrating power, and higher dose rate. Electron beams can be easily started and stopped by turning on and off the power supply thus represents a safer irradiation process. Besides, low penetrating power can be used as selective irradiation of surfaces. X-rays provide high penetrating power as the Gamma rays and it can be also stopped as electron beams (Sommers and Fan 2008). However, their energy conversion efficiency is low and the cost is much for nowadays technological conditions.

The electron beam irradiation (EBI) of foods has been shown an alternative and convenient method to reduce microorganism load without affecting the flavor of the foods. It is a fast and effective method for sterilization, of a variety of many foods. This method seems more reliable and safe to the consumers, because no radioactive source is needed and also it is more preferable for temperaturesensitive products (Silindir and Özer 2009). Some of the scientific committees have done some studies about EBI and have concluded that no problems in the irradiated foods with $10 \mathrm{MeV}$ electron beam (high energy level) at $30 \mathrm{kGy}$ in terms of nutritional changes, mutagenicity, microbiological safety and radioactivity (Kobayashi 2018).

Some studies have presented the efficacy of EBI for reducing pathogenic microorganisms in animal products. Wong and Kitts 2003; Kim et al. 2010 stated in their recent studies that EBI proved to be an effective method for controlling microbial growth in shell-eggs without adversely affecting physicochemical and functional properties and also for ground beef of low-fat content. In the studies, 
3 kGy absorbed dose for irradiation of the freshshell-eggs resulted in minor changes of proteins, lipids, or carbohydrates.

Although there is wide use of pathogen interventions as antimicrobial solutions for beef meat, outbreaks establish a connection with them exposed to such pathogen interventions continue. EBI is proposed to be the method of resolving these restrictions. Especially, EBI is proven by many studies as reducing the pathogens in meat and poultry products without damaging their quality. (Lewis 2002, Arthur et al. 2005, Duong et al. 2008, Kundu and Holley 2013, Maxim et al. 2014).

\section{MATERIALS and METHODS}

For industrial and medical applications electron beam accelerators process 0.15 to $10 \mathrm{MeV}$ electron beam energies. Energy and current are the important primary characteristics for these type of electron accelerators.

Electron beam applications of the food irradiation process can be classified as low energy surface applications and high energy irradiation. For surface treatment up to $400 \mathrm{keV}$ energetic electron beam energies are known to be sufficient (Blackburn 2017, Miller 2017). By application of low energetic electron beam to the surface of the food material, biological contaminants are removed efficiently with a little penetration depending on the electron beam energy. Approximately $15 \mathrm{~mm}$ penetration on the surface of the carcass sides is obtained including considerable radiation dose with this process. The pathogen contamination of carcass is a surface phenomenon. Thus, lower pathogen load without adverse affection of product organoleptic quality is expected by this application technique (Arthur et al. 2005).

The technical criteria for food irradiation are the irradiation dose and speed, penetration depth, processing speed. The average dose is the amount of energy absorbed by the material is divided by its mass, in the units of Gy as previously stated. High energy electrons immediately interact with the irradiated matter. Therefore, the absorbed dose is highest on the surface of the material and falls vertically towards the material depth. The input dose in the irradiated material is directly proportional to the electron beam current. Dose speed starts $10^{3}$ $\mathrm{Gy} / \mathrm{s}$ for electrostatic accelerators where it is $10 \mathrm{~Gy} / \mathrm{s}$ for radioisotope gamma sources. This is one of the advantages of electron accelerators in applications.

The penetration depth of the electrons in the material is directly proportional to the electron energy and inversely proportional to the density of the material to be irradiated. The penetration depth for given electron energy is given in terms of the weight of the material to be irradiated per unit area $\left(\mathrm{gr} / \mathrm{cm}^{2}\right)$. The biggest disadvantage of electron accelerators compared to gamma sources is that the material thickness to be irradiated is limited. Electron accelerators are more suitable for irradiation of grain, spices, small-sized fruits and vegetables, meat, and seafood packaged for daily consumption (Salimov et al. 2000). On the other hand, the material can be irradiated by scanning in two dimensions (with the inclusion of magnetic field) with accelerated electron beams. It causes the efficiency of the accelerators is to be larger compared to gamma sources. For example, by $50 \mathrm{~kW}$ electron beam, irradiation efficiency is 0,35 and irradiation dose is $2 \mathrm{kGy}$; around 30 tons of fresh white-poultry meat and red meat can be irradiated per hour for disinfection (Turhan et al.2020).

Nowadays, low dose, low penetration EBI technology has evolved to the point where large nonuniform surface areas can be effectively treated and an entire carcass side. A study indicated that low dose electron beam irradiation (lower than $2 \mathrm{kGy}$ ) could reduce some pathogens especially E.coli and S.typhimurium on inoculated shell eggs (Kim et al. 2010, 2016).

Irradiation of fish and meat need medium doses up to $10 \mathrm{kGy}$ to control pathogenic microorganisms in fresh or frozen meat. As referenced in Ferraira et al. 2018 for fish lower doses than 7kGy and lower than 3 kGy for eggs are needed. However, the permitted levels of irradiation are not sufficient to control the pathogenic viruses. Studies on EBI of beef surfaces presented that by this technique carcasses can be only irradiated on the surface and for lower depths (Arthur et al. 2005). By electron beams, surface structures such as fat and other external tissues are removed. For deep penetration, higher energetic electron beams are needed. To determine this, one may need to look at the curves for the distribution of absorbed dose along the beam direction (Ferraira et al. 2018).

For EBI process, as a source of radiation electron beams are needed to be generated by an electron beam linear accelerator or a Van de Graff generator. The electrons are accelerated and can reach to energies up to $10 \mathrm{MeV}$. The choice of a type of accelerator for a particular application is usually based on the application considerations (Cleland and Parks 2003, Cleland et al. 2003). There is a big interest in computer modeling for designing the irradiation apparatus and its operating environment. By modeling, the performance of an irradiator can be predicted and the optimization of the process can be done.

A schematic view of an accelerator-based system consists of an electron accelerator, a scanning system and a material handling system that the beam can move through the material. The electron accelerator 
is usually located inside the high voltage vacuum. In the accelerator tube generated electrons are accelerated and gain energy. Then these accelerated electrons escape through a thin window, usually titanium is preferred, and move through the target material.

To model an electron beam irradiation apparatus, important variables are electron beam energy, beam current and geometry, speed of the process, exit window foil thickness, the distance between exit window and the target material.

\section{RESULTS and DISCUSSION}

In this study, design and simulation of a low-energy electron-curtain-accelerator is presented. Design facilities are discussed in details, in conjunction with SIMION 3D electron trajectory simulation software. By SIMION 3D, calculation of charged particle trajectories in electric fields with a given configuration of electrodes, particle initial conditions, including optional magnetic field can be done (Scientific Instrument Services Inc.).

The majority of industrial installations in the low energy range base on the linear cathode concept. In this way, electrons distribute over a wide web of material that moves through the beam. A free electron is emitted by thermionic emissions by heating tungsten filament on the negative cathode side. The free electron is accelerated in the electric field and gain energy in electron volt $(\mathrm{eV})$. The production and acceleration of electrons are done inside a long evacuated vacuum tube (Ozer et al. 2017). The electrons emitted from the thermionic cathode are accelerated over a single stage to pass through the anode (a thin metallic window) producing a continuous stream of electrons to irradiate materials or products in atmospheric conditions (Auditore et al. 2013).

In Fig. 1 the Computer-Aided Design (CAD) model of the system (Dassault Systems Corp.).The designed electron accelerator consists of a $0.25 \mathrm{~mm}$ diameter $\mathrm{W}$ wire wrapped to provide a spring-shaped filament $150 \mathrm{~mm}$ long with a $1 \mathrm{~mm}$ diameter, emitting electrons by the thermionic effect. To convey the electrons emitted from the filament as a focal (parallel) beam on the anode a focusing electrode is used. The shape of this electrode is optimized for the desired beam shape. Also, a cylindrical high-voltage terminal that assists in focusing and reducing the potential gradient concerning the grounded shell is used.

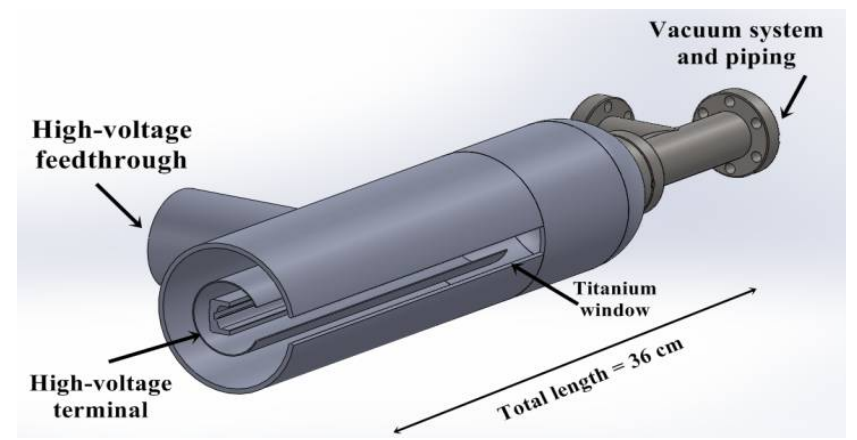

Figure 1. CAD model of the designed accelerator system.

For high voltage isolation, an electrically grounded cylindrical concentric shell to vacuum enclosure and minimizing voltage gradient is employed. To extract the accelerated electrons to the air a thin anode that forms a window as $150 \mathrm{~mm} \times 10 \mathrm{~mm}$ is created. A titanium foil with $20 \mu$ mthicknesses is preferred. The system is expected to work in pulse mode so a pulsed power supply system is expected to be used during the real construction. The electron beam is supposed to be uniformly distributed on the target material.

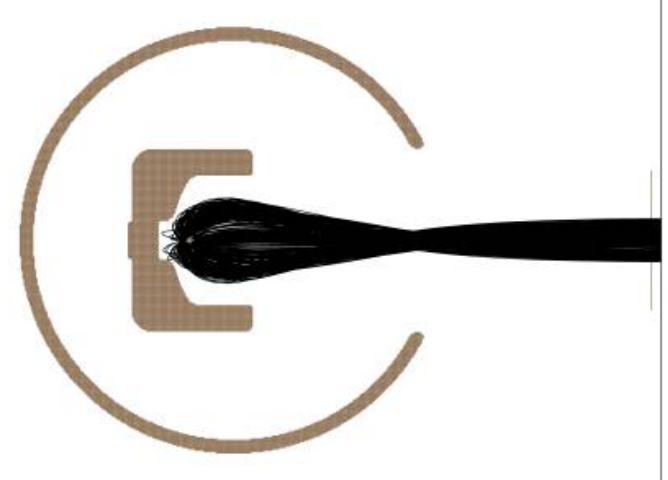

Figure 2. View of generated electron beam in SIMION and beam profile through the system. 
The focusing electrode and high voltage terminal design, and corresponding electron beam profile, as simulated with SIMION software, are shown in Fig. 2 and Fig. 3. About $90 \%$ of accelerated electrons from filament housing could successfully penetrate the titanium foil when the filament structure is $-200 \mathrm{kV}$ (or may arrange up to $-500 \mathrm{kV}$ ) relative to earth. Then the maximum electric field in vacuum is about 6.5 $\mathrm{MV} / \mathrm{m}$ near the round corner of high-voltage terminal, which is less than the critical electrical field $(20 \mathrm{MV} / \mathrm{m})$ in a high vacuum.
Dose distribution is one of the most important parameters of the irradiation process as mentioned previously, hence for reproducible process and heat diffusion on the exit window. In Fig. 3, beam distribution has shown at the exit foil of the window (red dots). Designed low energy electron accelerator has a compact design and expected as reliable in terms of beam uniformity, robustness, and high voltage safety.

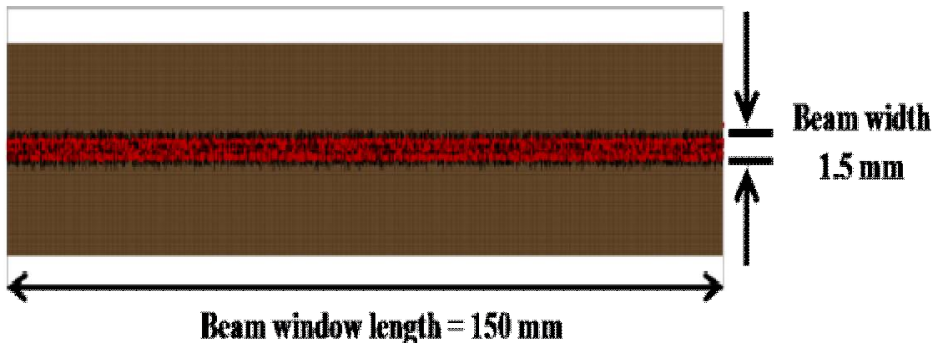

Figure 3. Beam distribution has shown at the exit foil of the window (red dots).

The exit window includes an exit window foil and a support grid contacting and supporting the exit window foil. The support grid has first and second grids, each having respective first and second grid portions that are positioned in an alignment and thermally isolated from each other. The first and second grid portions each have a series of apertures that are aligned for allowing the passage of a beam therethrough to reach and pass through the exit window foil. The second grid portion contacts the exit window foil. The first grid portion can mask the second grid portion and the exit window foil from heat caused by the beam striking the first grid portion. To prevent undue energy loss, the foil is preferably made as thin as possible while at the same time providing sufficient mechanical strength to withstand the pressure differential between the vacuum enclosure and irradiation atmosphere. As illustrated in the Fig.4, the heat problem can be solved by utilizing a titanium foil that has a thickness of 17 micrometers or less.

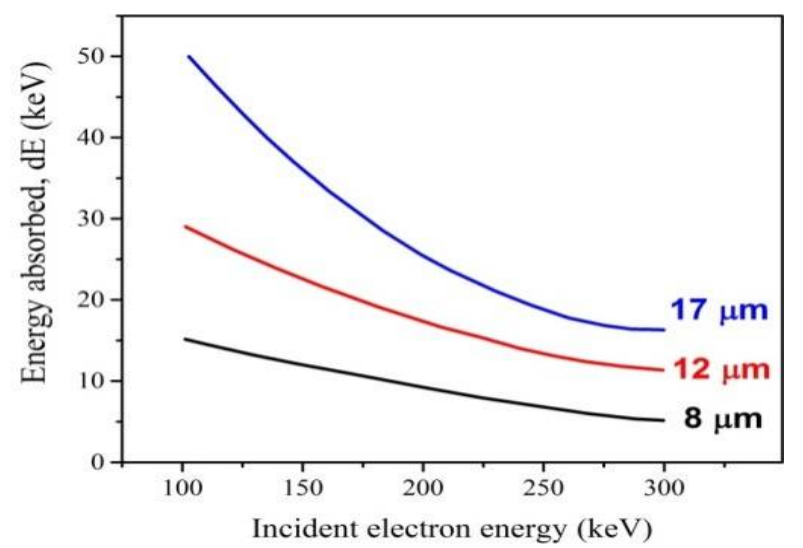

Figure 4. Exit window assembly.

In accordance with the principles of this study, the particle beam generating device can be made smaller in size and operate at a higher efficiency level when the thin foil of the exit window assembly is made of titanium or alloys thereof and having a thickness of $17 \mu \mathrm{m}$ or less, preferably in a range of $3-10$ micrometers. Alternatively, the foil may also be constructed of aluminum or alloys thereof having a thickness of $25 \mu \mathrm{m}$ or less.
Here, the design of a low electrostatic accelerator modeled in SIMION 3D program is described and some efforts to modulate exit window assembly have been done to optimize the heat dissipation on the exit foil. Electrons from a modified electron gun are injected into the tube and accelerated through the tube. Targets can be irradiated using an electron beam which energy can range below $500 \mathrm{keV}$ safely. Future studies are needed to be done for describing the dependence different beam current, dose and the 
adaption of exit window is In this process, thermal analysis of heat dissipation on foil and therewith active/passive cooling system for foil window is an important issue to be considered.

This study was carried out as the first step with the construction idea of a system that is planned to be made most appropriately, in the current laboratory conditions not thinking of commercial sterilization. The primary purpose of this study is to demonstrate the operability of such a system at low energies for applications such as sterilization on the surface of the target material. EBI facilities that serve in sector for commercial use are available in different purposes depending on the needs in the world.

This study is expected to be assisting further work for planned further work for the irradiation process of sterilization on the surface. It is possible to specify design of electron beam systems that have higher energies and serves medium doses in this field of the food industry for animal products. In this scale, for example, they may be used for surface sterilization of marketable eggs (only the shell and the outer thin white). This can be done with a proper selection of the energy and dose of electrons obviating considerable irradiation of the main egg contents.

\section{REFERENCES}

Anup R, Aparna V, Pulimood A, Balasubramanian KA. Surgical stress and the small intestine: role of oxygen free radicals. Surgery. 1999;125:560-569.

Arthur TM, WheelerT, Shackelford S D, Bosilevac J M, Nou X, Koohmaraie M. Effects of low-dose, low-penetration electron beam irradiation of chilled beef carcass surface cuts on Escherichia coli O157: H7 and meat quality. Journal of food protection. 2005; 68(4): 666-672.

Arvanitoyannis IS. Irradiation of food commodities: techniques, applications, detection, legislation, safety and consumer opinion. Academic Press, 2010.

Auditore L, Barnà RC, De Pasquale D, Interdonato S, Italiano A, Trifiró A,Trimarchi M.Compact $300 \mathrm{keV}$ electron gun for radiation processing. Review of scientific instruments. 2005; 76(12): 123301.

Blackburn C. Food Irradiation Technologies: Concepts, Applications and Outcomes. Royal Society of Chemistry. 2017.

Caja MM, Del Castıllo MR, Blanch GP. Solid-phase microextraction as a methodology in the detection of irradiation markers in ground beef. Food chemistry. 2008; 110(2): 531-537.

Cleland MR, Parks LA. Medium and high-energy electron beam radiation processing equipment for commercial applications. Nuclear Instruments and Methods in Physics Research Section B: Beam Interactions With Materials And Atoms. 2003; 208: 74-89.

Cleland MR,Parks LA,Cheng S. Applications for radiation processing of materials. Nuclear Instruments and
Methods in Physics Research Section B: Beam Interactions with Materials and Atoms. 2003; 208:66-73.

Dassault Systèmes Corp., USA. SolidWorks, www.solidworks.com Accessien date: 15.01.2020.

Duong DQ, Crandall PG, Pohlman FW, O'Bryan CA, Balentine CW, Castillo A. Improving ground beef safety and stabilizing color during irradiation using antioxidants, reductants or TSP. Meat science. 2008; 78(4): 359-368.

Farkas J and Farkas CM. History and future of food irradiaiton, Trends in Food Science and Techonology 2011; 22: 121126.

Farkas J. Charged particle and photon interactions with matter. Food irradiation. In A. Mozumder, Y. Hatano (Eds.); Basel: Marcel Dekker, Inc. New York, 2004;pp. 785-812.

Farkas J. Irradiation of poultry meat. In G. C. Mead (Ed.), Food safety control in the poultry Boca Raton/Cambridge: CRC Press/Woodhead Publ. Ltd., 2005; pp. 433-453.

Ferraira ICFR, Antonio AL, Verde SC. Food Irradiation Technologies Concepts, Applications and Outcomes, The Royal Society of Chemistry. 2018.

Goresline, HE. Historical aspects of the radiation preservation of food. In: preservation of food by ionizing radiation. CRC Press. 2018; p. 1-46.

Kim HJ, Yong HI, Jayasena DD, Lee HJ, Lee H, Jo C. Microbial safety and physicochemical characteristics of electron beam irradiated whole egg powder. Food science and biotechnology. 2016; 25(29: 637-642.

Kim HJ, Yun HJ, Jung S, Jung YK, Kim KH, Lee J W, JCU. Effects of electron beam irradiation on pathogen inactivation, quality, and functional properties of shell egg during ambient storage. Food Science of Animal Resources, 2010; 30(4): 603-608.

Kim HJ, Yun HJ, Jung S, Jung YK, Kim KH, Lee J W, Jo CU. Effects of electron beam irradiation on pathogen inactivation, quality, and functional properties of shell egg during ambient storage. Food Science of Animal Resources. 2010; 30(4): 603-608.

Kobayashi K, Yasuda H. Formation of a superstructure in 1TTiSe2 induced at room temperature by electron beam irradiation. Materials Research Express. 2018; 5(8): 085006.

Komolprasert V, Morehouse KM, Morehouse KMatthew. Irradiation of Food And Packaging. DC: American Chemical Society, Washington. 2004.

Korel F, Orman S. Gıda Işınlaması, Uygulamaları ve Tüketicinin Ișınlanmış Gıdaya Bakış Açısı Harran Üniversitesi Ziraat Fakültesi Dergisi. 2005; 9(2): 19-27.

Kundu D, Holley R. Effect of low-dose electron beam irradiation on quality of ground beef patties and raw, intact carcass muscle pieces. Journal of food science. 2013; 78(6): S920-S925.

Kwon JH, Kwon Y, Nam KC, Lee EJ, Ahn DU. Effect of electron-beam irradiation before and after cooking on the chemical properties of beef, pork, and chicken. Meat science. 2008; 80(3): 903-909. 
Lagunas-Solar MC. Radiation processing of foods. An overview of scientific principles and current status. Journal of Food Protection. 1995; 58:186-192.

Lewis SJ, Velasquez A, Cuppett SL. Effect of electron beam irradiation on poultry meat safety and quality. Poultry science. 2002; 81(6): 896-903.

Maxim JE, Neal JA, Castillo A. Development of a novel device for applying uniform doses of electron beam irradiation on carcasses. Meat science. 2014; 96(1): 373-378.

Miller RB, Antonio AL, Carreño I, Craven E, Strasser A, Kim J, Gryczka U.Food Irradiation Technologies: Concepts, Applications and Outcomes. Royal Society of Chemistry. 2017.

Min BR, Nam KC, Lee EJ, Ko GY, TrampelDW, Ahn DU. Effect of irradiating shell eggs on quality attributes and functional properties of yolk and white. Poultry science. 2005; 84(11): 1791-1796.

Molins R, Motarjemi Y, Käferstein F. Irradiation: a critical control point in ensuring the microbiological safety of raw foods. Food Control 2001; 12:347-356.

Olson D. Food irradiation future still bright. Food Technology. 2004;58(7): 112

Olson DG. Irradiation of food. Food Technology. 1998;52: 5662.

Ozer ZN, Yavuz M, Ozkan M, Yalım HA. Design and simulation of low-energy electron accelerator for industrial applications, 3rd International Conference on Theoretical and Experimental Studies in Nuclear Applications and Technology, 2017; 130.

Ozer ZN. Electron beam irradiation processing for industrial and medical applications. In: EPJ Web of Conferences. EDP Sciences. 2017; p. 01019.

Park JG, YoonY, Park JN, Han IJ, Song BS, Kim J H, Lee JW. Effects of gamma irradiation and electron beam irradiation on quality, sensory, and bacterial populations in beef sausage patties. Meat science. 2010; 85(2): 368372 .

Radomyski T, Murano EA, Olson DG, Murano PS. Elimination of pathogens of significance in food by lowdose irradiation: a review. Journal of food protection. 1994; 57(1):73-86.

Salimov RA, Cherepkov VG, Kuksanov NK, Kuznetzov SA. The use of electron accelerators for radiation disinfestation of grain. Radiation Physics and Chemistry. 2000, 57(3-6): 625-627.

Scientific Instrument Services Inc., USA. Simion, www.simion.com. Accession date: 02.03.2020.

Silindir M, Özer AY. Sterilization methods and the comparison of e-beam sterilization with gamma radiation sterilization. Fabad Journal of Pharmaceutical Sciences 2009; 34(1): 43.

Sommers CH, Fan X. Food irradiation research and technology. John Wiley \& Sons ed., 2008.

Taha SM. Incidence, toxigenicity and control of certain pathogenic bacteria in different environmental sources.
Ph.D. Thesis, Faculty of Science, Ain Shams University, Cairo, Egypt, 1999.

Turhan Ş, Karabacak H, Erel Y, Ocak ., Ünal S, Zengin T. Elektron hızlandırıcılarının gıda ışınlanması için değerlendirilmesi. 2002.

U.S. Department of Agriculture, Food Safety and Inspection Service. Food irradiation of meat food products, final rule. Fed. Regist.1999;64:72149-72166.

Wong PYY, Kitts DD. Physicochemical and functional properties of shell eggs following electron beam irradiation. Journal of the Science of Food and Agriculture. 2003; 83(1): 44-52.

Woodburn MJ, Raob CA. Household food following widely publicized outbreaks of foodborne illness. Journal of Food Protection, 1997; 60: 1105-1109. 